\title{
MODERN APPROACHES TO TRAINING COMPETITIVE LOCKSMITHS-ELECTRICIANS IN THE EU COUNTRIES
}

\begin{abstract}
The article deals with the issues of modern approaches to training competitive locksmiths-electricians and the influence of effective management on the process of vocational training. The modern labour market needs concerning vocational training of highly qualified workers have been analyzed. The concept of a competitive worker has been revealed and justified. The study has shown that nowadays the problems of training a modern, competitive and highly qualified locksmiths-electricians in the European Union countries are solved at the political level. The revealed arguments regarding vocational training of workers indicate that modern economics, in fact, transforms the subjects of study into the subjects of the European market. It has been indicated that vocational education institutions have become mediators between the student and the potential employer. In this regard, various approaches to vocational training of workers, namely, locksmiths-electricians, prove the topicality of vocational training itself as this sector ensures vast development of the workforce. It has been justified that competitiveness of the worker is correspondence of the level of their vocational training to the requirements of the European labour market. Competitiveness of locksmiths-electricians in European countries is a significant factor in competitiveness of the finished product, its qualitative and cost characteristics, which satisfy the maximum requirements of the consumer. It has been concluded that the above circumstances should encourage leadership of professional lyceums to seek such an essence and structure of vocational training of highly skilled workers, namely, locksmith-electricians who ensure the opportunity to provide appropriate "commodity condition" of the customer, a graduate of a professional lyceum. It has been added that perspectives for further researches are seen in studying didactic principles of vocational training of workers, namely, locksmiths-electricians, in leading European countries.

Keywords: management, competitiveness, labour market, vocational education, vocational lyceum, locksmith-electrician.

\section{INTRODUCTION}

Nowadays, society puts great hopes on reforming higher education, since this is an objective necessity. Unfortunately, the existing potential of the education system of Ukraine does not quite correspond to the modern needs of humanity.

Analyzing the requirements of the European labour market regarding vocational training of highly skilled competitive workers, namely, electrical locksmiths, one can see the employers' interest in quality training of specialists. It is possible to ensure it on the condition of a high qualification level, therefore, management of the educational institution should be oriented toward solving the considered problem.
\end{abstract}


The achievements in scientific discoveries and introduction of the latest technologies provide for quality training of workers of the highest qualification level. This requires knowledge of modern technologies, development of the individual's ability to adapt to the labour market in Ukraine and other European countries in the context of constantly increasing competition.

\section{THE AIM OF THE STUDY}

The aim of the study is to analyze and theoretically justify methodological approaches to training highly qualified competitive workers in vocational lyceums of Ukraine and other European countries.

\section{THEORETICAL FRAMEWORK AND RESEARCH METHODS}

Theoretical framework of our research consists of thw works by prominent European scholars. In particular, we have considered the works by M. Brockmann, L. Clarke, \& Ch. Winch (2011), F. Bünning (2007), J.-M. Castejon, B. Chakroun, M. Coles, A. Deij \& V. McBride (2011), R. H. Mulder \& P. F. E. Sloane (2004), J. Olofson \& D. P. Thunqvist (2014), G. Sprecht, O. Ahnfeld \& Ch. Reichert (2008). In addition, we have taken into accounts the report by the European Commission, namely, Communication from the Commission. Europe 2020. A strategy for smart, sustainable and inclusive growth (2010), as well as relevant data on vocational education and training in European countries presented on the official website of the organization; the data provided by Cedefop; the report of Swiss Confederation on Vocational and Professional Education and Training in Switzerland.

While researching we have used such methods analysis and synthesis, generalization, systematization and individualization.

\section{RESULTS}

During the last years, vocational education and training (VET) have become one of the fastest growing sectors in many countries. This can be explained by the fact that 1) the system of vocational education is part of the structure of development of highly qualified workforce, meeting the needs of society and individuals in various professions; 2) this system of education is an integral part of a unified education system; 3) vocational education performs functions of social protection of a large part of the population that requires the state support. Under these market conditions, VET should become one of the effective ways of ensuring employment of the population, gaining priority in the system of measures to improve the quality of the workforce, regulating professional structure of supply and demand for it. Nowadays in Ukraine, one can observe contradictions between the labour market needs for skilled workers in different fields and their vocational training in unpopular occupations. That is, the VET system does not take into consideration the needs of economics, the labour market (in connection with the economic crisis, a significant number of workers have been dismissed, the activities of enterprises have been partly suspended, etc.). In order for the VET to adequately regulate the changes taking place in the labour market, it is necessary to introduce new mechanisms of their interaction, such as the relationship between vocational schools and employment centers, the structure and the volume of workers' training, training profilization, a contractual system of the relations with enterprises, determination of workforce needs based on monitoring studies.

Studying topical needs of the labour market for professional training of highly qualified competitive locksmiths-electricians, it becomes clear that modern employers, in particular foreign ones, are interested in quality training. Therefore, administration of an educational institution, namely a professional lyceum, should actively participate in solving this particular issue. 
One of the first steps in Ukraine's approaching the European community was the Bologna process - a modern educational brand. There have been organized numerous scientific conferences, $\mathrm{PhD}$ and doctoral thesis on the issue of European integration of professional higher and secondary education have been written and defended. However, certain problematic issues are still on the agenda.

Due to the fact that Ukraine is a member of different international organizations in the European educational space, it is important to study foreign experience in training highly qualified workers and the possibilities of its adapting to our conditions. The dynamic process of social development is closely linked to the rapid changes in quantitative parameters of national education systems, in particular the mass dissemination of compulsory secondary, as well as higher education, the emergence of new conceptual approaches to organization, content and teaching methods, conceptual development of lifelong learning. One of the most important aims of continuing education is diversification and expansion of educational services complementing general education or higher education. The experience of countries with a developed market economy shows a direct dependence of the pace of improvement and development of production, its competitiveness in the world market on the level of professional training.

The European Commission (2010) indicates in its Communication Europe 2020: A strategy for smart, sustainable and inclusive growth, that initial vocational education and training (VET) aims to 'equip young learners with skills directly relevant to evolving labour markets'. Based on Cedefop's definition, VET refers to 'education and training which aims to equip people with knowledge, know-how, skills and/or competences required in particular occupations or more broadly on the labour market' (European Commission, 2010).

It should be mentioned that unlike employment and occupational health and safety policies, the EU has been reluctant to regulate VET, symbolized in the tendency to regard as a "no-competence" issue. Indeed, VET has long been one of the few areas in which government have been able to subside producers without infringing competition policy. However, this does not mean that VET has been immune from regulation as part of the labour market policy (Castejon, Chakroun, Coles, Deij, \& McBride, 2011; Mulder, \& Sloane, 2004).

The 1995 White Paper on general and vocational education marked the acceleration of this process. It set out a number of principles concerning the necessary evolution of VET systems to fulfill the needs what came to be called the "information" society, laying the foundations for a more active European intervention in the field of qualifications. The Lisbon Summit and, in the field of VET, its ramifications (often called the BrugesCopenhagen process) enlarged European intervention while significantly changing its overall context. The question of labour mobility remained, while general and vocational education policies were incorporated into a macro-economic and social strategy, often summoned in the phrase "The Europe of Knowledge". The contribution of general and vocational education was considered to be central to the development of an economic model founded on knowledge, as well as to social cohesion in Europe and realization of a "European social model". With the rising influence of lifelong learning, the borders between general and vocational education were put into question. Active and coordinated policies, which included but went beyond the question of qualifications, then developed with the help of a variety of old and new instruments (Brockmann, Clarke, \& Winch, 2011).

Thus, in European countries, the vocational education system development is adequate to the needs of economics. In order to coordinate vocational training, social 
programmes implementation was established by the European Center for the Development of Vocational Training (Cedefop). The Cedefop helps to develop and implement EU vocational training policies. It monitors the labour market trends and helps the European Commission, EU countries, employers' organisations and trade unions to match training provision to them (European Union, 2017). Each EU country has its own system of vocational training and its state regulation. In Denmark, for instance, there are national trade committees of continuing vocational training (CVT), in Germany - Federal and Land Committees and the Federal Institute for Vocational Education and Training (BIBB). In the Netherlands, state and regional authorities for vocational training jointly develop curricula and monitor implementation of training contracts concluded by employees with the directorates of enterprises. In Belgium, the National Employment Office manages the activities of the vocational training centers (European Commission, 2017).

The state and the level of a future locksmith-electrician's practical training is one of the important features of a skilled worker's competitiveness in the world labour market. Students need to obtain not only sufficient skills and knowledge of the chosen occupation; they should be able to use them in everyday situations. The term "creative self-realization" is recognition of personal professional motives and interests, the ability to apply knowledge in new circumstances for solving production tasks, the ability to independently manage professional activity in production. The standard of professional competency of creative personality is public importance of the results of locksmiths-electricians' activities, the final product and credibility of the worker in a particular field of activity. Professional competency of a graduate of a professional lyceum influences their competitiveness in the European labour market. Therefore, it is crucially important to what extent this influence is facilitated by the learning environment.

According to the Executive Summary on Guidelines for German Financial Cooperation Projects and Programmes, titled "Innovative Approaches to Promoting Vocational Training and Employment", the following approaches should be taken into account, namely, 1) promoting vocational training institutes based on criteria, 2) promoting selected institutes or "competence centres", 3) training funds, 4) voucher programmes, 5) training loans/student loans, 6) indirect financing of vocational training by way of other priorities (Sprecht, Ahnfeld \& Reichert, 2008). In our opinion, further consideration deserve the approaches directed at promoting criteria-based vocational training institutes and implementing voucher programmes, since their positive aspects may be used by Ukrainian work groups to enhance efficiency of the national VET system.

Thus, the multilevel approach to promoting vocational training institutes by criteria includes institute-specific promotion contingent on criteria; open programme approach: multilevel selection procedure in competition; preparation of development/business plans for each institute as a central planning basis; minor amount of preliminary work prior to project appraisal by shifting the institute-specific analysis and planning to the implementation phase; synchronous planning and implementation of investments, advanced training/ consulting and counterpart contributions; targeted promotion of specific vocational areas or training forms. Thus, support should be given particularly to those training institutes offering relevant training that is in line with demand and of satisfactory quality. The most important eligibility criteria for promotion are: 1) relevance of training for the labour market, practical relevance and imparting of skills needed in professional activity; 2) minimum qualifications of teaching and management staff; 3) appropriate legal status, organisational 
structure and efficiency; 3) financial stability of operating institution (Sprecht, Ahnfeld \& Reichert, 2008).

Speaking about voucher programmes, vouchers are instruments needed for effectively subsidising the use of training programmes or enterprise-related services. They are a demand-oriented instrument and represent an alternative to traditional supply-oriented models (institute-related promotion). The features of the approach are the following: 1) vouchers provide users/the target group with the freedom to choose the services they wish to buy and the source (promotion of the demand side);2) they are lever for market development on the supply side; 3 ) they are usually subsidies with varying contributions from the target group; thus they are not a revolving mechanism; 4) they can be coupled with a loan component as a general rule; 5) they may cause a high risk of abuse, so they require a high monitoring effort and administrative costs. So, voucher programmes also may pursue varying objectives: either to permanently subsidise services or public goods that have a political priority for certain target groups (vouchers as a long-term instrument) or the development of service markets (temporary instrument) (Sprecht, Ahnfeld \& Reichert, 2008).

However, professional lyceum should provide graduates, namely, future locksmithselectricians not only with the opportunity to obtain a qualification, but also ensure conditions for personal development on the way to professional growth. Close cooperation of the educational institution with employers, practical classes and employment at the factories that are the customers of the workforce plays a significant role. Improvement and fulfillment of the working sector requirements by highly qualified and competitive European specialists demands continuing monitoring and adjustment of the methodology of teaching professional disciplines and production training.

In all European countries, colleges and universities are involved in vocational training, as well as contacts are established between vocational schools and enterprises. Continuing training of the workforce in the EU countries is carried out full- and part-time. Part-time training involves practical training in the enterprise and a theoretical course in a vocational school or a specialized center. This training system is preferred in Germany and Denmark. Part-time training is carried out in secondary vocational schools and training centers. Such a training system prevails in France and Italy. In Great Britain and the Netherlands, both full- and part-time vocational training is common (European Commission, 2017).

The use of modern pedagogical tools and technologies creates favourable conditions for achieving successful results through the best selection and allocation of resources. This greatly enhances the chances of solving such a complex task of pedagogy as forming creative personality of a socially adapted graduate, competitive in the European labour market. As modern educational technologies, interactive styles of teaching, the original forms of activities that allow future locksmiths-electricians to organize personal educational activities under the conditions at most approximated to real working conditions ensure expected outcomes.

It must be noted that changes taken place in the Swedish VET model during the 20th century can be nowadays considered as a regulated school-based vocational education at the post-compulsory level movement, although it used to be unregulated apprenticeship. The Swedish government have attempted to provide the initial, school-based vocational training with the final training of qualified workers that is regulated by collective agreements. However, these attempts have been only realized partially. After the university-oriented model of upper secondary school was established in the 1990s, one could probably observe the final point in the Swedish vocational education model development in an academic 
direction. Today, the interest of trade and industry in the process of defining employability concerning education and competency requirements has enhanced. The latest reform on upper secondary school has presented great opportunities to cause an influence, for instance, through national and local councils. Yet, it does not concern only transformations in the training process of upper secondary vocational education. It also provides for using professional boards and other educational organizations to ensure opportunities for advanced vocational learning outside the upper secondary school and the regular educational system. Agreements on vocational introduction in certain trades constitute one tangible expression of the creation of opportunity (Olofson \& Thunqvist, 2014).

Quite interesting are training arrangements in VET in Switzerland. To begin with, the VET system in this country is based on three approaches, namely, work-based training, classroom instruction and industry courses. With the dual approach to learning, trainees attend part-time courses at vocational schools. The rest of the training time is spent doing an apprenticeship at a host company where they are provided with the practical know-how, knowledge and skills needed for their chosen occupation. Learners also actively take part in the host company's production processes. Host company networks (in some cases, host companies) may wish to combine their strengths to offer one or more apprenticeships in a modular format.

VET schools also provide classroom instruction. This consists of instruction in vocational subjects as well as subjects falling under the Language, Communication and Society (LCS) category. Classroom instruction is intended to develop social, methodological and technical skills of learners while imparting the theoretical and general principles needed to perform occupational tasks. Classroom instruction covers one or two days per week. VET schools also offer a preparatory course for the Federal Vocational Baccalaureate Examination.

Industry courses are meant to complement classroom instruction at VET schools and work-based training at host companies by providing learners with essential practical skills. Industry courses often take place at third-party training centres run by the industries involved (Swiss Confederation, 2013).

F. Bünning (2007) believes that the teaching and learning processes in VET should be transformed. Common models of these processes, which imply formal training, are usually not linked to the peculiarities of real practice. He states that the action learning method pioneered by British professor R. Revans in the 1960s provides enhancing learning that enables individuals to cope with complicated situations more efficiently. The outlined concepts of action learning are project-based learning, case study, role play, programmed instruction and experiment.

Thus, competitiveness of the worker is correspondence of the level of their vocational training to the requirements of the European labour market. Competitiveness of locksmiths-electricians in European countries is a significant factor in competitiveness of the finished product, its qualitative and cost characteristics, which satisfy the maximum requirements of the consumer.

\section{CONCLUSIONS}

So, the study shows that nowadays the problems of training a modern, competitive and highly qualified locksmiths-electricians in the countries of European Union are solved at the political level. These revealed arguments regarding vocational training of workers indicate that modern economics, in fact, transforms the subjects of study into the subjects of the European market. Vocational education institutions become mediators between the student and the potential employer. Various approaches to vocational training of workers, 
namely, locksmiths-electricians, prove the topicality of vocational training itself as this sector ensures vast development of the workforce.

The above circumstances should encourage leadership of professional lyceums to seek such an essence and structure of vocational training of highly skilled workers, namely, locksmith-electricians who ensure the opportunity to provide appropriate "commodity condition" of the customer, a graduate of a professional lyceum.

Perspectives for further researches are seen in studying didactic principles of vocational training of workers, namely, locksmiths-electricians, in leading European countries.

\section{REFERENCES}

1. Brockmann, M., Clarke, L., \& Winch, Ch. (Eds.). (2011). Knowledge, skills and competence in the European labour market. New York, NY: Routlege.

2. Bünning, F. (2007). Approaches to action learning in technical and vocational education and training (TVET). Retrieved from http://www.unevoc.unesco.org/fileadmin/ user_upload/pubs/ActionLearning.pdf.

3. Castejon, J.-M., Chakroun, B., Coles, M., Deij, A., \& McBride, V. (Eds.). (2011). Developing qualifications frameworks in EU partner countries. London; New York, NY; Delhi: Anthem Press.

4. European Commission. (2010). Communication from the Commission. Europe 2020. A strategy for smart, sustainable and inclusive growth. Retrieved from http://ec.europa.eu/eu2020/pdf/COMPLET\%20EN\%20BARROSO\%20\%20\%20007\%20\%20Europe\%202020\%20-\%20EN\%20version.pdf.

5. European Commission. (2017). Vocational education and training (VET). Retrieved from http://ec.europa.eu/education/policy/vocational-policy_en.

6. European Union. (2017). European centre for the development of vocational education (Cedefop). Overview. Retrieved from https://europa.eu/european-union/abouteu/agencies/cedefop_en.

7. Mulder, R. H., \& Sloane, P. F. E. (Eds.). (2004). New approaches to vocational education in Europe. The construction of complex learning-teaching arrangements. Oxford: Symposium Books.

8. Olofson, J., \& Thunqvist, D. P. (2014). The Swedish model of vocational education and training - establishment, recent changes and future challenges. Retrieved from http://nord-vet.dk/indhold/uploads/report 1a_se.pdf.

9. Sprecht, G., Ahnfeld, O., \& Reichert, Ch. (2008). Innovative approaches to promoting vocational training and employment. Executive summary on guidelines for German Financial Cooperation projects and programmes. Retrieved from https://www.kfwentwicklungsbank.de/Download-Center/PDF-Dokumente-Sektoren-

Berichte/2008_06_Berufsbildung_kurz_E.pdf.

10. Swiss Confederation. (2013). Vocational and professional education and training in Switzerland. Facts and figures. Retrieved from https://edudoc.ch/record/106675/ files/EN_FaktenZahlen_2013.pdf. 